Aneta Jegier* (D) https://orcid.org/0000-0003-2492-4876

Akademia Pedagogiki Specjalnej w Warszawie

https://doi.org/10.25312/2083-2923.18/2020_01aj

\title{
Opiekun w żłobku - \\ zadania, odpowiedzialność i oczekiwane kompetencje
}

\begin{abstract}
Streszczenie: Artykuł zawiera analizę sytuacji zawodowej i oczekiwań wobec opiekunów w żłobku. Jego celem jest ukazanie złożoności obowiązków nałożonych na opiekujących się małymi dziećmi. Autor poprzez zestawienie wymagań prawnych wobec opiekunów z realiami ich codziennej pracy pokazuje trudności w sprostaniu tym wymaganiom. Złożoność zadań, ogromna odpowiedzialność za los najmłodszego pokolenia oraz oczekiwane kompetencje opiekunów nie przekładają się bowiem na stworzone im przez pracodawców warunki pracy. Poruszony problem zmusza do refleksji i podjęcia naukowych rozważań nad rozwiązaniami prawnymi i organizacyjnymi związanymi z pracą opiekunów.
\end{abstract}

Słowa kluczowe: małe dziecko, żłobek, opiekun w żłobku

\section{Wstęp}

W dzisiejszych czasach żłobki dają rodzicom małych dzieci nie tylko możliwość realizacji pracy zawodowej, ale także zapewniają komfort wysokiej jakości opieki, wychowania i edukacji podopiecznych. Trudno przecenić poczucie bezpieczeństwa matek i ojców, którzy z pełnym przekonaniem przekazują swoje dzieci w ręce opiekunów w żłobku. Dlatego tak ważne jest zatrudnianie pracowników mających kompetencje

Aneta Jegier - doktor nauk humanistycznych, adiunkt w Akademii Pedagogiki Specjalnej im. Marii Grzegorzewskiej w Warszawie, w Katedrze Pedagogiki Małego Dziecka. Od trzech lat pełni funkcję kierownika żłobka publicznego w Warszawie. Prezes Stowarzyszenia na Rzecz Wspomagania Rozwoju Dzieci ze Specjalnymi Potrzebami Edukacyjnymi. Zajmuje się problematyką wychowania i kształcenia dzieci w wieku żłobkowym i przedszkolnym oraz innowacjami pedagogicznymi w obszarze relacji dorosły-dziecko. Autorka książek i artykułów dotyczących wspomagania dzieci w dobrym funkcjonowaniu w domu, żłobku i przedszkolu. 
do zajmowania się dziećmi i stwarzających optymalne warunki dla ich rozwoju. Według obowiązującego prawa (Ustawa z dnia 4 lutego 2011 r. o opiece nad dziećmi w wieku do lat 3) żłobki są instytucjami sprawującymi opiekę nad małymi dziećmi w okresie od ukończenia 20. miesiąca życia do roku, w którym kończą trzeci rok i rozpoczynają przedszkole. Tylko w uzasadnionych przypadkach możliwe jest przebywanie dziecka do czwartego roku życia. Prawo zobowiązuje żłobek do:

„1. zapewnienia dzieciom opieki w warunkach bytowych zbliżonych do warunków domowych,

2. zagwarantowania właściwej opieki pielęgnacyjnej oraz edukacyjnej, przez prowadzenie zajęć zabawowych z elementami edukacji, z uwzględnieniem indywidualnych potrzeb dzieci,

3. prowadzenia zajęć opiekuńczo-wychowawczych i edukacyjnych, uwzględniających rozwój psychomotoryczny dzieci, właściwych do ich wieku" (Ustawa $\mathrm{z}$ dnia 4 lutego 2011 r. o opiece nad dziećmi w wieku do lat 3).

Ustawa o opiece nad dzieckiem do lat 3 określa wymagania kwalifikacyjne opiekunów w żłobku. Mogą nimi być osoby posiadające: dyplom pielęgniarki, położnej, opiekuna dziecięcego, nauczyciela wychowania przedszkolnego, edukacji wczesnoszkolnej, pedagoga opiekuńczo-wychowawczego, społeczno-wychowawczego, wczesnej edukacji, terapeuty pedagogicznego lub osoby, które ukończyły studia lub studia podyplomowe na kierunkach lub specjalności: wczesne wspomaganie rozwoju, wspomaganie rozwoju dzieci w ramach pomocy psychologiczno-pedagogicznej w żłobkach i przedszkolach, edukacja prorozwojowa, pedagogika małego dziecka, psychologia dziecka, psychologia wspierania rozwoju i kształcenia lub psychologia wychowawcza. Opiekunem w żłobku lub klubie dziecięcym może być także osoba, która posiada wykształcenie średnie lub średnie branżowe i odbyła 280 -godzinne szkolenie przed zatrudnieniem.

Kwalifikacje opiekunów zostały określone w ustawie, ale w żadnym akcie prawnym nie znajdziemy wytycznych odnośnie do wymagań, jakim człowiekiem musi być osoba zajmująca się małym dzieckiem. Warto więc zastanowić się, jaki powinien być opiekun dziecięcy. Niektórzy powiedzą, że taki jak dobry nauczyciel. Ma on z życzliwością i troską dbać o wszechstronny rozwój dzieci oraz wspierać rodziców w ich trudach wychowania. Warunkiem budowania bezpiecznego przywiązania dziecka do opiekuna jest ich fizyczna bliskość. Jak pisze Rudolph Schaffer, są trzy poziomy bliskości i relacja dziecka z opiekunem powinna przebiegać na wszystkich tych poziomach równocześnie. Te poziomy to: bliskość obok siebie, bycie razem i bycie w jedności ${ }^{1}$. Istotną kwestią jest wrażliwość opiekuna na potrzeby dziecka, która pozwala dorosłemu na dostosowanie swojego zachowania, swojej relacji do preferencji podopiecznego.

${ }^{1}$ H.R. Schaffer, Rozwój języka w kontekście, [w:] A. Brzezińska (red.), Dziecko w zabawie i świecie języka, Zysk i S-ka, Poznań 1995, s. 173. 


\section{Osobowość opiekuna jako podstawa oddziaływań pedagogicznych}

Każdy opiekun musi zdawać sobie sprawę, że pomiędzy nim a dzieckiem zachodzi sprzężenie zwrotne. W psychologii wyjaśnia to teoria równowagi interpersonalnej². Im młodsze dziecko, tym bardziej ma nasiloną potrzebę równowagi w relacjach z opiekunem, dlatego odwzajemnia się za życzliwość chęcią sprawienia przyjemności dorosłemu. W takiej sytuacji dziecko czuje się niejako w obowiązku sprostać wymaganiom opiekuna i wzrasta jego motywacja oraz chęć do zachowywania się w taki sposób, w jaki oczekuje od niego opiekun. W tym wieku dzieci chcą swoim zachowaniem sprawiać przyjemność dorosłym i być przez nich chwalone. Inaczej jest w sytuacji, gdy opiekun przyjmuje postawę nieżyczliwości, poniżania dziecka - wtedy może wywołać zachowania lękowe u dzieci. Maluchy demonstrują to niechęcią do żłobka, a nawet zachowaniami wegetatywnymi. Dlatego tak ważne jest, aby opiekun małych dzieci posiadał takie cechy i umiejętności psychopedagogiczne, które pozwolą mu w pełni realizować swoje powinności względem dzieci.

$\mathrm{Na}$ podstawie analizy literatury przedmiotu oraz biorąc pod uwagę katalog cech i umiejętności wzorcowych, sporządzony przez Stanisława Korczyńskiego ${ }^{3}$, uważam, że opiekun w żłobku powinien posiadać takie właściwości psychopedagogiczne, jak:

- Dojrzałość emocjonalna. Jest niezbędna w pracy z dziećmi. Warunkuje adekwatne do sytuacji zachowanie opiekuna, samokontrolę w sytuacjach trudnych. Praca z dziećmi to wyzwanie dla emocji. Nigdy nie można do końca przewidzieć, co się wydarzy w grupie. Ważne jest, aby umieć opanować zdenerwowanie i działać dojrzale. To opiekun ma pokazać dzieciom, że w sytuacjach trudnych należy zachować spokój i działać adekwatnie do potrzeb.

- Ukształtowany charakter i tolerancyjność. Opiekun to człowiek, który jest wzorem dla swoich podopiecznych. Pełni rolę modela, którego małe dzieci naśladują. Na każdym kroku powinien mieć świadomość, że jego postawa, ton głosu, gesty, reakcja na różne sytuacje będą miały niebagatelny wpływ na wychowanków.

- Wykazywanie troski o wszechstronny rozwój dzieci. Opiekun w żłobku ma wpływ na to, jakie podejście do wychowywania dziecka będą mieć jego bliscy. Wielu rodziców po zajęciach w żłobku lub w weekendy zapisuje dzieci na dodatkowe zajęcia. W takich przypadkach ważne jest, aby uzmysłowić rodzicom, że bez równowagi pomiędzy rozwojem fizycznym i intelektualnym ich pociecha nie będzie wykazywać należytych postępów. Sam opiekun także powinien pamiętać, jak ważny dla dzieci jest ruch i pobyt na świeżym powietrzu.

2 Z. Zaborowski, Psychologiczne problemy wychowania, Nasza Księgarnia, Warszawa 1977.

${ }^{3}$ S. Korczyński, Satysfakcja zawodowa nauczycieli jako stan świadomości wyznaczony stopniem zaspokajania potrzeb związanych z praca pedagogiczna, [w:] S. Korczyński (red.), Nauczyciel i uczeń $w$ zreformowanej szkole, Uniwersytet Opolski, Opole 2006. 
- Zdolność krytycznego myślenia. Opiekun planuje zajęcia z dziećmi i organizuje zabawy. To od niego zależy, jakie zabawki podsunie dzieciom. Znajomość potrzeb dzieci, ich nastrojów, stopnia zmęczenia itp. sprawia, że może on modyfikować wcześniejsze zamierzenia, tak aby dzieci jak najwięcej skorzystały i z chęcią przystępowały do zajęć.

- Umiejętność budowania poczucia własnej wartości dzieci. W każdym dziecku można znaleźć pozytywne strony i je uwypuklić. Ważne, aby pamiętać, że dzięki naszym staraniom zmianie może ulec postrzeganie siebie przez dzieci. Dzieci starają się jeszcze bardziej, bo wiedzą, że ich pani je za to pochwali.

- Cierpliwość i wytrwałość. Te cechy są wysoko cenione w zawodach, które związane są z opieką nad dziećmi. Każdy opiekun wie, że nie zawsze efekty jego pracy przychodzą natychmiast, że niektóre dzieci potrzebują dłuższego czasu do zinterioryzowania przekazywanej wiedzy.

- Empatia, czyli rozumienie dziecka, umiejętność wczucia się w jego przeżycia. Opiekun dysponujący wiedzą o specyfice rozwoju i rozumowania dziecka w wieku żłobkowym będzie lepiej przygotowany do wczucia się w sytuację dziecka, zrozumienia go i podjęcia takich kroków, które, nie raniąc dziecka, będą pomocne w rozwiązaniu trudnych sytuacji.

- Umiejętność aktywnego słuchania dzieci, nawet jeśli ich mowa jest nie w pełni zrozumiała. Umiejętności związane z dobrym słuchaniem to połowa pedagogicznego sukcesu. Warto słuchać, co dzieci mają do powiedzenia, zachęcać do samodzielnego poszukiwania rozwiązań, podsuwać sugestie. Dobry słuchacz to taki, który delikatnie zachęca do mówienia, stosuje parafrazy (powtórzenie własnymi słowami najważniejszych treści wypowiedzi rozmówcy), używa rekapitulacji (podsumowania najważniejszych informacji i ustaleń) oraz klaryfikowania (wyjaśniania tego, co niezrozumiałe i niejasne podczas rozmowy, co pomaga zrozumieć wypowiedź). Aktywne słuchanie to też mowa ciała, pokazywanie rozmówcy, że jest dla nas ważny i istotne jest dla nas to, co ma nam do powiedzenia.

- Umiejętności diagnostyczne i terapeutyczne. Dobry opiekun sam zauważy, kiedy dziecko ma zły dzień, a kiedy dzieje się z nim coś niepokojącego. Ważne, aby umiał w porę zareagować. Jest to trudne, bo żeby tego dokonać, trzeba umieć obserwować dziecko, a potem umiejętnie wspomagać jego rozwój.

- Umiejętność współdziałania z rodzicami. Opiekun dziecięcy to osoba, która umiejętnie słucha i udziela rad rodzicom w sposób dla nich pomocny, zrozumiały oraz przekazany ciepło i życzliwie. Potrafi zrozumieć problemy rodziców małych dzieci. Jest otwarta na ich potrzeby, a także wspiera ich w skutecznym wypełnianiu roli rodzica.

- Gotowość i zdolność doskonalenia zawodowego. Współczesny człowiek jest zmuszony poszerzać swoją wiedzę. Ten, kto tego nie robi, nie tylko stoi w miejscu, ale się cofa. Postęp, jakiego jesteśmy świadkami, zmusza ludzi, którzy mają wychowywać innych, aby sami stale się doskonalili i nadążali za zmianami. 
- Samoakceptacja. Jeśli lubię siebie, to lubię też innych - to znana maksyma. Warto o niej pamiętać, wychowując młode pokolenie.

Wymienione umiejętności wzorcowe pokrywają się w dużej mierze z wymaganiami dotyczącymi awansu zawodowego opiekunów w warszawskich żłobkach publicznych. Ocena oparta jest na badaniu siedmiu obszarów kompetencji: współpracy w zespole, rozwoju asertywności, nastawienia na rodziców, nastawienia na własny rozwój, poszukiwania nowych rozwiązań w pracy, wysokiej etyki zawodowej oraz rozwijania metod pracy z dziećmi. Od wykształcenia, stażu pracy i poziomu kompetencji zależy awans zawodowy opiekuna.

W zawodzie opiekuna w żłobku jego postawa jest równie ważna jak wiedza i umiejętności. Cechy opisujące dobrego opiekuna to: kreatywność, uczciwość, odpowiedzialność, wytrwałość, entuzjazm, jak również umiejętność motywacji swoich podopiecznych i wspierania rodziców w ich trudnej rodzicielskiej roli. Dlatego istotne jest, aby w każdej żłobkowej placówce znaleźli się wychowawcy, którzy z pasją będą wykonywać swój zawód i staną się wzorem dla tych mniej doświadczonych.

Zawód opiekuna dziecięcego nie jest prestiżowy, nie niesie ze sobą wysokiego uposażenia, ale jest misją. Wiemy, jak ważne dla rozwoju człowieka są pierwsze lata życia. I te właśnie lata małego dziecka w dużej mierze zostają powierzone opiekunom. Jest bowiem wiele dzieci w żłobku, które przybywają do placówki skoro świt i wychodzą po ustawowo przysługujących im dziesięciu godzinach. Tak więc to opiekun ma niebagatelny wpływ na ich rozwój. Jak pisze Katarzyna Sadowska: „Opiekun dziecka do lat trzech jest pierwszym nauczycielem dziecka poza jego środowiskiem rodzinnym. Opiekun [...] zna indywidualne potrzeby i możliwości swojego podopiecznego [...], ma największą wiedzę o sposobach stymulowania rozwoju dziecka w zakresie lokomocji, komunikacji i manipulacji, stymulowania dziecka w sytuacji tu i teraz, tworzenia przestrzeni fizycznej i społecznej adekwatnej do bieżących potrzeb"

\section{Wywiad z opiekunami w żłobku - badania i ich jakościowa analiza}

Poniżej przedstawiono rezultaty wywiadu $\mathrm{z}$ opiekunami jednego $\mathrm{z}$ warszawskich żłobków publicznych. Wypowiadali się oni na temat istotnych w ich pracy zadań, organizacji pracy w żłobku oraz wymaganych w ich pracy kompetencji.

Badania wpisują się w nurt podejścia strukturalnego i procesualnego. To pierwsze dotyczy warunków pracy opiekunów, jak również stawianych im wymagań. Drugie zaś - ich relacji z podopiecznymi. Uzyskane wyniki mają charakter dość subiektywny, gdyż konstruowane były lokalnie i ograniczały się do jednego środowiska. Zdobyta wiedza może jednak stanowić punkt wyjścia do refleksji nad tym, jak wygląda praca

${ }^{4}$ K. Sadowska, Wczesnodziecięca edukacja w żłobku, Wydawnictwo Naukowe UAM, Poznań 2019, s. 181. 
opiekunów, co jest ważne i jakie zmiany należy zainicjować dla podniesienia jakości pracy w żłobkach, a tym samym stworzenia lepszych warunków rozwoju najmłodszym podopiecznym.

\section{Zadania w ocenie opiekunów}

Najważniejszym zadaniem opiekunów jest zapewnienie dzieciom bezpieczeństwa. Wszystkie wypowiadające się osoby podkreślały, że nie ma nic ważniejszego niż życie i zdrowie ich podopiecznych. Wczesne dzieciństwo wiąże się z coraz sprawniejszym poruszaniem się dzieci. To zaś umożliwia im coraz bardziej samodzielne przemieszczanie się, aby dotrzeć do interesujących je ludzi i przedmiotów. Dzieci potrzebują wielu wrażeń, które znajdują poprzez chodzenie tam, gdzie same chcą, co często oznacza wchodzenie w kałuże, pokonywanie krawężników i innych nierówności, dotykanie wszystkiego po drodze i zatrzymywanie się przy każdej rzeczy, która przyciągnęła ich uwagę. „Chodzenie daje im pierwsze i miłe poczucie autonomii. Wcale bowiem nie lubią chodzić tam, gdzie my je prowadzimy, ale każda napotkana po drodze kupka kamieni stanowi okazję do wdrapania się i w ten sposób do umocnienia własnej siły"s.

Możliwość samodzielnego poruszania się sprawia, że podopieczni żłobków nie tylko mogą dotrzeć do przedmiotów, które je zaciekawią, ale mogą je wziąć do rąk, manipulować nimi i dowiadywać się, do czego służą oraz co można z nimi zrobić. To bardzo istotne dla rozwoju poznawczego, gdyż w ten sposób poszerza się dziecięca wiedza o świecie. Ciekawość podopiecznych wymaga jednak od opiekunów przygotowania przestrzeni bezpiecznej dla dziecka. W tym celu zabezpiecza się rogi stołów, regały i szafki przymocowuje się do ściany, zabezpiecza się gniazdka elektryczne. W ogródku żłobkowym codziennie sprawdza się bezpieczeństwo zabawek, podłoża, jak również roślinność, na przykład czy nie wyrosły jakieś kłujące rośliny, grzyby, czy nie pojawily się jakieś owoce, zdrowe dla ptaków, ale nie dla dzieci itp. Najlepszym sposobem zadbania o bezpieczeństwo jest jednak wprowadzenie reguł i konsekwentne ich przestrzeganie ${ }^{6}$.

Kolejnym ważnym zadaniem stojącym przed opiekunami jest, jak sami twierdzą, poznawanie wraz z dziećmi świata i wyjaśnianie rządzących nim praw. Według Kingi Kuszak „Jednym z ważniejszych zadań opiekuna małego dziecka jest budowanie rusztowania, a więc pośredniczenie między jednostką a światem zewnętrznym"7. Odpowiedzialny opiekun wraz z dzieckiem bada i poznaje świat. Potrafi znaleźć sposoby na skoncentrowanie uwagi dziecka na czymś ważnym oraz opowiada o przedmiotach i wyjaśnia sytuacje, które rozgrywają się wokół. Stara się zainteresować dziecko światem, ukazując emocje w celu wspólnego przeżywania. Opiekun podtrzymuje

\footnotetext{
${ }^{5}$ M. Debesse, Etapy wychowania, Wydawnictwo Akademickie Żak, Warszawa 1996, s. 37.

${ }^{6}$ K. Appelt, Wiek poniemowlęcy. Jak rozpoznać potencjat dziecka?, [w:] A. Brzezińska (red.), Psychologiczne portrety człowieka, Gdańskie Wydawnictwo Psychologiczne, Gdańsk 2005, s. 95-131.

${ }^{7} \mathrm{~K}$. Kuszak, Małe dziecko wśrodowisku dorostych. O budowaniu pozytywnej więzi z opiekunem, [w:] H. Krauze-Sikorska, K. Kuszak, G. Rura, K. Sadowska, Dziecko do lat trzech w systemie opieki i edukacji. Źródła wsparcia i zagrożeń, Wydawnictwo Naukowe UAM, Poznań 2016, s. 82.
} 
interakcje, nawiązując i przedłużając kontakt wzrokowy. Zachęca dziecko do aktywności, motywuje do dalszych działań, do podejmowania wyzwań, dostrzega dobre zachowania i chwali je. W budowaniu rusztowania ważna jest intrasubiektywność. Jak pisze Rudolph Schaffer, istotne jest określenie wspólnego tematu, na którym dorosły i dziecko skoncentrują swoją uwagę ${ }^{8}$. Obrazowo przedstawiła to Edyta Gruszczyk-Kolczyńska9 ${ }^{9}$, opisując przebieg zabawy z wieżą Hanoi. Otóż dorosły zaczął od ustalenia z dzieckiem wspólnego pola uwagi. Podał dziecku zabawkę, pokazując mimiką i gestami, jak jest ona atrakcyjna. Następnie wraz z dzieckiem zaczyna tworzyć wspólne pole działania. Gdy dziecko zaspokoiło już swoją ciekawość i obejrzało dokładnie zabawkę przy udziale dorosłego, ten dostrajając się do dziecięcej aktywności i dążąc do jej ukierunkowania, pokazuje sposób konstrukcji, prowokując dziecko do dalszej manipulacji. Dziecko włącza się do wspólnego działania, próbując naśladować czynności dorosłego. Nawet jeśli próba nie powiedzie się, dorosły modeluje raz jeszcze sposób tworzenia konstrukcji, przekazując następnie wieżę dziecku. Pamiętać należy, że dorośli muszą pilnie obserwować reakcje dzieci. Jak zauważa Gruszczyk-Kolczyńska, „Gdyby dorosły przymuszał dziecko do aktywności, które przekraczają tu i teraz jego możliwości, wyzwoliłby zachowania obronne" ${ }^{10}$. Gdy zaś propozycje dorosłego mieszczą się w strefie najbliższego rozwoju dziecka, ono z radością angażuje się w ustalenie wspólnego pola uwagi i uczestniczy w działaniach.

Małe dziecko w żłobku musi mieć zapewnioną uwagę dorosłego i jego wsparcie w trudnych sytuacjach. Opiekunowie uczestniczący w wywiadzie byli zgodni, że dziecko przychodzące do żłobka musi móc nawiązać bliską relację z opiekunami. Dzięki temu buduje więź osobową, co jest nieodzownym warunkiem prawidłowego rozwoju maluchów. Opiekuna można porównać do kreatora rzeczywistości. To on pomaga dzieciom zrozumieć otaczający świat. Pomaga dostrzec, co jest dobre, a co złe, uczy odróżnić prawdę od kłamstwa. Opiekun posiada duży autorytet, dlatego też każda wypowiedź opiekuna, jego zasady, sposób wyrażania się i zachowania są niezwykle ważne dla wychowanka ${ }^{11}$. Problem w tym, że małe dzieci najwięcej korzyści czerpią z pracy w układzie „jeden do jednego”, a w żłobku na jedną opiekunkę przypada ośmioro dzieci. Wtedy organizując proces uczenia się dzieci, dobrze jest wykorzystywać „efekt zarażania”. Jak zapewnia Gruszczyk-Kolczyńska, jest to możliwe, jeśli dorosły sprawi, że choć jedno dziecko zaciekawione tym, co się dzieje, zechce usiąść

${ }^{8}$ H.R. Schaffer, Psychologia rozwojowa. Podstawowe pojęcia, Wydawnictwo Uniwersytetu Jagiellońskiego, Kraków 2010, s. 158-159.

${ }^{9}$ E. Gruszczyk-Kolczyńska, Jak w społecznym uczeniu się małe dzieci korzystaja z naśladownictwa i modelowania. Naśladownictwo i modelowanie wzabawach równoległych $w$ żłobku oraz w przedszkolu, [w:] E. Gruszczyk-Kolczyńska (red.), Wspomaganie rozwoju i wychowywanie matych dzieci. Podręcznik dla rodziców, opiekunów w żłobkach i nauczycieli w przedszkolach, Bliżej Przedszkola, Kraków 2019.

10 Tamże, s. 81.

${ }^{11} \mathrm{~J}$. Bałachowicz, Style działań edukacyjnych nauczycieli klas początkowych. Między uprzedmiotowieniem a podmiotowością, Wydawnictwo Wyższej Szkoły Pedagogicznej TWP, Warszawa 2009. 
obok niego, a wówczas inne dzieci też się przyłączą. To tworzy początek skupienia uwagi na wspólnym polu działania i naśladowaniu czynności dorosłego. „Ukierunkowane przez dorosłego wykonają nowe dla nich czynności, jeżeli mieszczą się one w strefie najbliższego rozwoju"12.

Szacunek wobec dziecka jest jednym z priorytetów zdaniem opiekunów uczestniczących w wywiadzie. W związku z tym, że do żłobka uczęszczają bardzo małe, niedojrzałe jeszcze dzieci, wymagają one szczególnej opieki i ochrony. Niedopuszczalne jest więc stosowanie jakichkolwiek form przemocy czy to fizycznej, czy psychicznej lub emocjonalnej. Nie wolno stosować straszenia, krzyku, wyśmiewania, manipulacji, prawienia kazań czy grożenia. Dorośli przebywający z dziećmi powinni wykazywać się dojrzałą postawą: okazywać dziecku szacunek, zaspokajać jego potrzeby, obdarzać życzliwą uwagą. Jednocześnie powinni panować nad swoimi emocjami i słowami kierowanymi do dziecka. Relacje opiekunów z dziećmi mają dawać wsparcie, ciepło i poczucie bezpieczeństwa. Konieczne jest aktywne słuchanie, nawiązywanie kontaktu wzrokowego, przytulanie, pocieszanie, wspólna zabawa, dzielenie smutków i radości. Dyscyplinowanie zachowania dziecka to konieczne i konsekwentne stawianie granic, wyjaśnianie, co wolno, a czego nie wolno.

Szacunek wobec dziecka jest niezbędny w uczeniu dzieci czynności samoobsługowych. To kolejne wymienione przez opiekunów zadanie, które przed nimi stoi. Jest ono nie tylko trudne, ale wymagające delikatności. Jak sprawić, żeby czynności, które zazwyczaj zawstydzają dorosłych, stały się powodem do dumy dla dzieci. Bowiem samodzielne korzystanie z toalety to krok milowy w rozwoju dziecka. Opiekunowie muszą wykazać się ogromną cierpliwością i taktem. Każde dziecko ma prawo do opanowywania czynności fizjologicznych w indywidualnym tempie. Nauce czystości nie może towarzyszyć zawstydzanie i upokarzanie dziecka, a przeciwnie - radość z osiąganych efektów. Niedopuszczalne jest okazywanie rozczarowania w sytuacji, gdy dziecko załatwi się w ubranie czy też zabrudzi je podczas toalety.

\section{Wymagania wobec opiekunów}

W samym środowisku pracowników żłobków rodzą się wątpliwości co do standardów kwalifikacji opiekunów, sposobów oddziaływania wobec dzieci, a także znajomości jednolitych kryteriów pracy z dziećmi do lat trzech. Nie ma bowiem żłobkowej podstawy programowej, jak również programów ze scenariuszami do pracy z małymi dziećmi. Wszyscy jednak są zgodni, że opiekunowie powinni znać prawidłowości rozwojowe małych dzieci oraz ich indywidualne potrzeby rozwojowe i planować zajęcia, pamiętając, że zabawa jest podstawową aktywnością małych dzieci. Podczas zabawy dziecko może decydować, czym, w jaki sposób i jak długo będzie się bawić. Uczestnictwo w zabawie jest dobrowolne. Tak samo jest z zajęciami. Dzieci nie mają obowiązku uczestniczenia w nich i jest to ich prawo. Jednak nie mogą wtedy przeszkadzać innym dzieciom i powinny o tym wiedzieć. Proces uczenia się musi być

\footnotetext{
${ }^{12}$ E. Gruszczyk-Kolczyńska, dz. cyt., s. 83.
} 
zgodny z naturalnym rozwojem dzieci, dostosowany do ich możliwości umysłowych, a jednocześnie przyjazny ${ }^{13}$.

Jako duży problem jawi się jakość relacji opiekunów z rodzicami. Opiekunowie biorący udział w wywiadzie krytycznie odnosili się do postaw rodzicielskich prezentowanych przez rodziców ich podopiecznych. Przywoływali wiele przykładów negatywnych zachowań rodziców zarówno w kwestii wychowania dzieci, jak i zachowania się względem personelu w placówce. Jest to niewątpliwie istotny problem, gdyż żłobki pełnią wobec rodziców funkcję usługową i życzliwość opiekunów względem rodziców powinna być podstawą ich relacji. Niezależnie od tego, w jakiej rodzinie żyje i wychowuje się dziecko, każdy opiekun powinien mieć na uwadze fakt, że dziecko jest dzieckiem swoich rodziców. Wiadomo, że do rodziców należy właściwa opieka, wychowanie i troska o dalsze dorosłe życie dziecka, tym samym do nich należy też wspomaganie w rozwoju i przystosowywaniu do wymagań społecznych. W literaturze przedmiotu znajdziemy wiele refleksji teoretycznych i doniesień $z$ badań na temat znaczenia rodziny dla rozwoju i wychowania dziecka. W żłobkowych realiach oczywistością jest współpraca opiekunów z rodzicami w celu stwarzania warunków dla właściwego funkcjonowania dziecka w społeczeństwie, w rodzinie, w gronie rówieśników, w placówce, jak też poza nią. Nie wolno dzielić rodzin na dobre i złe, lecz mimo czasem znaczących problemów starać się przede wszystkim pomagać rodzinom i samym dzieciom w korzystaniu z tego, co dobre. Szczególnie, że „w sytuacji nieprawidłowego funkcjonowania najbliższego środowiska dziecka jak najbardziej zasadne wydaje się wsparcie rodziny przez inne osoby, które mogą zbudować z nim pozytywne relacje sprzyjające korzystnym zmianom rozwojowym i niwelowaniu szkód, jakie przynosi relacja $\mathrm{z}$ matką" ${ }^{14}$.

\section{Podsumowanie - refleksje z praktyki pedagogicznej}

W Standardach dotyczących opieki złobkowej napisano: „Ustawa nazywa osoby pracujące z dziećmi w wieku do 3 lat «opiekunami/opiekunkami». Tymczasem ich zadania, zakres odpowiedzialności i oczekiwane kompetencje znacznie przekraczają funkcje opiekuńcze”15. Twórcy Standardów optują za funkcją „wychowawcy małych dzieci”. Problem jednak nie w nazwie, a w ogromie obowiązków, jakim musi sprostać opiekun dziecięcy. Zgodnie z ustawą jeden opiekun może zajmować się maksymalnie ośmiorgiem dzieci. Jeśli analizie poddamy listę obecności pracowników i rejestr dzienny dzieci, to w większości placówek praca przebiega zgodnie z prawem. Jednak

${ }^{13}$ E. Gruszczyk-Kolczyńska, E. Zielińska, Dwulatki i trzylatki w przedszkolu $i$ w domu. Jak świadomie je wychowywać i uczyć, Bliżej Przedszkola, Kraków 2012, s. 43-73.

14 K. Kuszak, dz. cyt., s. 89.

15 M. Rościszewska-Woźniak, Standardy jakości opieki i wspierania rozwoju dzieci do lat 3, Fundacja Rozwoju Dzieci im. J.A. Komeńskiego, Warszawa 2012, s. 8. 
jeżeli przeanalizujemy relacje dzieci z opiekunami w czasie dnia, nie będzie to już takie oczywiste. Na przykład gdy frekwencja dzieci jest wysoka, w grupie 25 dzieci pracuje czterech opiekunów. Jeśli jeden z nich jest nieobecny, a zarządzający placówką nie może oddelegować opiekuna $z$ innej grupy, to wówczas praca opiekunów jest niezgodna z prawem. Inna sytuacja dotyczy obowiązków, którym muszą sprostać osoby zajmujące się małymi dziećmi. Oprócz opieki, wychowania, edukacji dzieci do ich obowiązków należy między innymi przygotowanie pomocy do zajęć, wydanie posiłków, posprzątanie po nich, przygotowanie leżaków do spania i potem ich złożenie. Wypełnienie tych zadań zmusza opiekunów do odejścia od dzieci i w rzeczywistości w tym czasie na jedną osobę dorosłą - opiekuna przypada znacznie więcej dzieci. Nie bez powodu we wspomnianych wcześniej Standardach M. Rościszewska napisała: „Małe dziecko musi mieć zapewnioną stałą uwagę, wsparcie czy pomoc osoby dorosłej - zapewnia to warunki do budowania wysokiej jakości relacji między opiekunami i dziećmi”'16. Potrzeba stałej uwagi dorosłego zmusza nas bowiem do głębszego przeanalizowania realiów pracy opiekunów w żłobku.

Kompetencje, jakie powinien posiadać opiekun dziecięcy, są wysokie. Tworzenie rzeczywistości dostępnej dla małego dziecka, sprawianie, że będzie ono lepiej rozumiało, co się wokół niego dzieje, to trudne zadanie. Wiąże się ono z ogromną odpowiedzialnością. Podkreślmy, że także z odpowiedzialnością karną. Dlatego ważne jest, żeby zarówno decydenci, pracodawcy, jak i rodzice mieli świadomość roli, jaką odgrywają opiekunowie małych dzieci w opiece, wychowaniu i edukacji, a co za tym idzie kształtowaniu przyszłego społeczeństwa. Osoby zajmujące się badaniem realiów opieki żłobkowej powinny patrzeć krytycznie na opiekę świadczoną najmłodszym, aby reprezentowała ona jak najwyższy poziom, zapewniający podopiecznym $\mathrm{z}$ jednej strony bezpieczeństwo, a z drugiej - wszechstronny rozwój.

\section{Bibliografia}

Appelt K., Wiek poniemowlęcy. Jak rozpoznać potencjał dziecka?, [w:] A. Brzezińska (red.), Psychologiczne portrety człowieka, Gdańskie Wydawnictwo Psychologiczne, Gdańsk 2005.

Bałachowicz J., Style działań edukacyjnych nauczycieli klas poczatkowych. Między uprzedmiotowieniem a podmiotowościa, Wydawnictwo Wyższej Szkoły Pedagogicznej TWP, Warszawa 2009.

Debesse M., Etapy wychowania, Wydawnictwo Akademickie Żak, Warszawa 1996.

Gruszczyk-Kolczyńska E., Jak w społecznym uczeniu się małe dzieci korzystają z naśladownictwa i modelowania. Naśladownictwo i modelowanie w zabawach rów-

${ }^{16}$ Tamże, s. 7. 
noległych w żłobku oraz w przedszkolu, [w:] E. Gruszczyk-Kolczyńska (red.), Wspomaganie rozwoju i wychowywanie matych dzieci. Podręcznik dla rodziców, opiekunów w żłobkach i nauczycieli w przedszkolach, Bliżej Przedszkola, Kraków 2019.

Gruszczyk-Kolczyńska E., Zielińska E., Dwulatki i trzylatki w przedszkolu i w domu. Jak świadomie je wychowywać i uczyć, Bliżej Przedszkola, Kraków 2012.

Gurycka A., Bład w wychowaniu, WSiP, Warszawa 1990.

Korczyński S., Satysfakcja zawodowa nauczycieli jako stan świadomości wyznaczony stopniem zaspokajania potrzeb związanych z praca pedagogiczna, [w:] S. Korczyński (red.), Nauczyciel i uczeń w zreformowanej szkole, Uniwersytet Opolski, Opole 2006.

Kuszak K., Małe dziecko wśrodowisku dorostych. O budowaniu pozytywnej więzi zopiekunem, [w:] H. Krauze-Sikorska, K. Kuszak, G. Rura, K. Sadowska, Dziecko do lat trzech w systemie opieki i edukacji. Źródła wsparcia i zagrożeń, Wydawnictwo Naukowe UAM, Poznań 2016.

Rościszewska-Woźniak M., Standardy jakości opieki i wspierania rozwoju dzieci do lat 3, Fundacja Rozwoju Dzieci im. J.A. Komeńskiego, Warszawa 2012.

Sadowska K., Wczesnodziecięca edukacja w żłobku, Wydawnictwo Naukowe UAM, Poznań 2019.

Schaffer H.R., Psychologia rozwojowa. Podstawowe pojęcia, Wydawnictwo Uniwersytetu Jagiellońskiego, Kraków 2010.

Schaffer H.R., Rozwój języka w kontekście, [w:] A. Brzezińska (red.), Dziecko w zabawie i świecie języka, Zysk i S-ka, Poznań 1995.

Ustawa z dnia 4 lutego 2011 r. o opiece nad dziećmi w wieku do lat 3, Dz.U. 2011, nr 45, poz. 235.

Zaborowski Z., Psychologiczne problemy wychowania, Nasza Księgarnia, Warszawa 1977.

\section{Carer of a young child - tasks, responsibility and expected competences}

Abstract: The article contains an analysis of the professional situation and expectations of child carers. Its purpose is to show the complexity of duties imposed on caring for young children. The author, by comparing the legal requirements for carers with the reality of their daily work, shows difficulties in meeting these requirements. The complexity of tasks, huge responsibility for the fate of the youngest generation, and the expected competences of carers do not translate into the working conditions created by employers. The problem raised, forces reflection and scientific considerations on legal and organizational solutions related to the work of carers.

Keywords: young child, nursery, carer of a young child 


\section{About the Author:}

Aneta Jegier - doctor of Humanities, assistant professor at the Maria Grzegorzewska Unia versity in Warsaw, Centre of Little Children's Pedagogy. For three years she has been the manager of a public nursery in Warsaw. She is President of the Association for Supporting the Development of Children with Special Educational Needs. She deals with the issues of upbringing and education of children of nursery and preschool age and pedagogical innovations in the area of adult-child relations. Author of books and articles on helping children to function well at home, at nursery and at kindergarten. 